\title{
Assessing the exposure of German and Austrian bird ringers to West Nile virus (Flavivirus) and evaluating their potential risk of infection
}

\author{
Sonja Linke · Marion Muehlen • Matthias Niedrig · Heinz Ellerbrok • \\ Andreas Kaiser · Wolfgang Fiedler · Karen Sonnenberg · Katharina Alpers • \\ Klaus Stark · Georg Pauli
}

Received: 26 July 2007/Revised: 10 December 2007/ Accepted: 10 December 2007/Published online: 9 January 2008 (C) Dt. Ornithologen-Gesellschaft e.V. 2007

\begin{abstract}
West Nile virus (WNV) is a mosquito-borne Flavivirus with birds as its natural reservoir. Mosquitoes are able to transmit WNV to humans. In Europe, WNV is most probably imported by migrating birds from WNVendemic regions. In this study, the risk of WNV infection during bird-ringing activities in Germany and Austria was investigated. Several serological test systems were used to study WNV antibody prevalence among 137 bird ringers. Neutralising antibodies were detected in three of the bird ringers. This seropositivity could be explained by alternative factors such as traveling to endemic areas. The application of different serological methods showed that WNV IgG ELISAs were less specific than WNV IgG immunofluorescence tests (IFT). The neutralisation test
\end{abstract}

Communicated by F. Bairlein.

S. Linke and M. Muehlen have contributed equally to this manuscript.

S. Linke $\cdot$ M. Muehlen $\cdot$ M. Niedrig $\cdot$ H. Ellerbrok .

K. Alpers · K. Stark · G. Pauli $(\bowtie)$

Robert Koch-Institut, Nordufer 20, 13353 Berlin, Germany

e-mail: paulig@rki.de

\section{A. Kaiser}

University of Mainz, Mainz, Germany

W. Fiedler

Vogelwarte Radolfzell at Max Planck Institute for Ornithology,

Radolfzell, Germany

K. Sonnenberg

EUROIMMUN AG, Lübeck, Germany

Present Address:

M. Muehlen

Theoretical Epidemiology Group,

Instituto Gulbenkian de Ciência (IGC),

Oeiras, Portugal
(NT) appears to be the gold standard for Flavivirus differentiation. At present, we assume that bird-ringing activity in Germany and Austria harbours a very low risk of WNV infection.

Keywords West Nile virus - Zoonosis . German and Austrian bird ringers · Epidemiology · Serological test systems

\section{Introduction}

Factors like international travel and trade, interaction between man and wildlife, climatic changes, and destruction of ecosystems have led to the emergence and spread of infectious diseases in many regions of the world (Marano and Pappaioanou 2004; Sutherst 2004; Gubler 2001). In recent years, zoonotic diseases like West Nile fever (WNF) were introduced into new geographic regions with a large impact on public health management. The emergence of West Nile virus (WNV) in New York in 1999 and its rapid spread across large parts of the Americas attracted worldwide attention (Reisen and Brault 2007). WNV is an arbovirus of the genus Flavivirus in the family Flaviviridae. Birds are the natural reservoir of WNV, but mosquito species feeding on both birds and mammals can transmit the virus from its avian host to humans.

Migrating birds are considered as an important carrier in spreading WNV over long distances. It is assumed that WNV epidemics in Southern and Central Europe are due to the introduction of the virus by migrating birds (Hubalek 2000; Savage et al. 1999). WNV outbreaks have been observed in Mediterranean countries since the early 1950s (Malkinson et al. 2002). In contrast to the epidemiological situation in North and South America, all 
outbreaks in Europe were temporally and regionally restricted. So far, no endogenous WNV infections in humans have been reported for Germany, but data on WNV prevalence have not been collected systematically. To estimate the exposure to WNV of persons with close contact to migrating birds, we investigated the WNV seroprevalence in German and Austrian bird ringers. Because of the bird ringers' close contact to wild birds, especially migratory birds, and their prolonged exposure to wildlife habitats, including those of mosquitoes, we assumed bird ringers to be at an increased risk for acquiring a WNV infection if WNV was regularly imported by migrating birds into Germany. This group was also selected since reports have shown that North American turkey farm workers with close contact to WNV-seropositive turkeys showed a high seroprevalence of WNV antibodies, indicating that direct transmission of WNV may have occurred during handling of the animals (MMWR 2003). Furthermore, transmissions from birds to humans were described in laboratories during necropsy of WNV-infected birds (MMWR 2002).

\section{Methods}

In February 2004 and in March 2005, bird ringers from southern Germany and Austria and from northern and eastern Germany, respectively, were recruited on the occasion of their annual meetings. The response rate among the participants was high (about 91\% for southern Germany and Austria, $\sim 71 \%$ for eastern and $\sim 53 \%$ for northern Germany, overall average approximately $75 \%$ ). Bird ringing is mainly provided on a voluntary basis. The study was approved by the ethical committee in charge, and participants gave their written informed consent prior to enrolment. A questionnaire regarding demographic characteristics, past and present medical history, risk behaviour during bird-ringing activities, travel to WNVendemic areas, and immunisation status was completed by all participants. EpiInfo Version 3.3 (CDC Atlanta, USA) was used for data entry and analysis. Blood samples from bird ringers were collected during the two meetings and sera were stored at $-20^{\circ} \mathrm{C}$ until use.

Blood samples were analysed using the following commercially available ELISA tests: Focus Technologies, Cypress, Calif., USA; EUROIMMUN, Lübeck, Germany; and Panbio, Brisbane, Australia. Commercially available immunofluorescence test (IFT) slides (EUROIMMUN) were used, following the instructions of the manufacturer. ELISA and IFT results were confirmed by a WNV neutralisation test (NT) considered as the gold standard test which was established as an in-house assay (Linke et al. 2007).

\section{Results and conclusions}

In total, 138 bird ringers participated in the study with a mean age of 53 years (range 22-74 years), and 137 sera were included in the seroprevalence studies. More than half of them $(51 \%)$ reported perennial ringing activities, $37 \%$ during summer and $25 \%$ during autumn. Late summer and early fall are seasons during which WNV outbreaks were observed in Europe and bird migration and mosquito density are at peak levels (Malkinson et al. 2002; Rappole et al. 2000). Nearly $85 \%$ of the participants ringed longdistance migrants and $64 \%$ sustained injuries by the birds (through pecking and scratching) during ringing. In total, $89 \%$ of all bird ringers reported exposure to mosquito bites during ringing activities and $67 \%$ of them reported evening and night ringing activities which exposed them to frequent mosquito bites. However, only $22 \%$ of the participants "always" used repellents and $21 \%$ "sometimes". When asked about personal protection equipment during ringing, only $6 \%$ reported wearing gowns, $4 \%$ wore gloves and only $1 \%$ wore masks, indicating that protection measures of bird ringers were inadequate regarding the potential risk of zoonotic infections. A high proportion of the ringers $(57 \%)$ had been immunised against tick-borne encephalitis virus (TBEV) or yellow fever virus (YFV).

ELISA and IFT were used as screening assays and the neutralisation test as confirmation test. As no information on the reactivity of the sera in serological assays from persons immunised against flaviviruses was available, all sera were investigated in the different test formats. Among 137 sera screened, only $3(2.2 \%)$ showed WNV-specific antibodies using the NT, 2 of which with a titre of 1:10 and 1 with a titre of 1:80. All NT-positive samples were reactive in at least two different ELISA tests and the IFT. However, the proportion of reactive sera in the different WNV ELISAs varied substantially from 4.4\% (EUROIMMUN) to $40.0 \%$ (PanBio). Using IFT, 12 of the 137 samples $(8.8 \%)$ reacted with antigens of WNV-infected cells. Table 1 shows the reactivities of sera in different WNV serological test systems.

Table 1 Reactive sera from bird ringers $(n=137)$ in different serological WNV test systems

\begin{tabular}{|c|c|c|}
\hline Test system & $\begin{array}{l}\text { Number of } \\
\text { reactive sera }(n)\end{array}$ & $\begin{array}{l}\text { Percentage of } \\
\text { reactive sera }(\%)\end{array}$ \\
\hline ELISA, IgG Panbio $^{\circledR}$ & 55 & 40.0 \\
\hline ELISA, IgG EUROIMMUN & 6 & 4.4 \\
\hline ELISA, IgG Focus ${ }^{\circledR}$ & 34 & 24.8 \\
\hline IFT, IgG EUROIMMUN & 12 & 8.8 \\
\hline $\begin{array}{l}\text { Neutralisation test, } \\
\text { in-house assay }\end{array}$ & 3 & 2.2 \\
\hline
\end{tabular}


This high proportion of reactive sera in the screening tests could probably be explained by the high number of participants $(51.1 \%)$ who had been immunised against TBEV and/or YFV. Of the 76 bird ringers from southern Germany, an endemic region for TBEV, 53 (69.7\%) had either been immunised against TBEV or had contracted an infection with TBEV, whereas persons ringing in the northern part of Germany $(n=61)$ showed significantly lower immunisation rates $(27.9 \%)$. Correlating the WNV ELISA results with the vaccination status, it was remarkable that vaccinated persons were significantly more likely to show a reactivity in at least one of the WNV ELISAs than the non-vaccinated group (Table 2).

Considering the WNV NT as the gold standard for diagnosing WNV infection, the results of the ELISA and IFT should be interpreted with caution. In our investigations, up to $40 \%$ of the sera were reactive in one screening assay, showing that a high proportion of sera from individuals vaccinated against or previously infected with other flaviviruses were reactive in ELISA and/or IFT. Comparable results were published by Hogrefe et al. (2004), who used the WNV IgG ELISA (Focus), demonstrating a reactivity of $35 \%$ of sera from vaccinated or naturally flavivirus-infected individuals. The importance of using neutralisation tests to differentiate between antibodies directed against different flaviviruses was shown by Chiles and Reisen (1998). In addition, a serological study investigating sera from individuals vaccinated against Japanese encephalitis virus or against Dengue virus, using an experimental Dengue virus vaccine, showed that immunisation against these flaviviruses did not induce a measurable titre of cross-neutralising antibodies against WNV using the NT (Kanesa-Thasan et al. 2002).

We cannot conclude that the neutralising antibodies against WNV of the three bird ringers were due to birdringing activities in Germany. There is strong evidence for the assumption that at least two of these three bird ringers had been infected with WNV during their stays in WNVendemic regions. The bird ringer with an NT titre of 1:80 reported prolonged stays in sub-Saharan Africa where he probably contracted the infection. One of the two other bird ringers with an NT titre of 1:10 also reported prolonged stays in WNV-endemic regions, whereas the third bird

Table 2 Number of ELISA-reactive samples correlated with vaccinated (against FSME, YFV) and non-vaccinated bird ringers

\begin{tabular}{llllll}
\hline ELISA, IgG & \multicolumn{2}{l}{ Vaccinated $(n=78)$} & & \multicolumn{2}{l}{ Non-vaccinated $(n=59)$} \\
\cline { 2 - 3 } \cline { 5 - 6 } & $n$ & $\%$ & & $n$ & $\%$ \\
\hline PanBio $^{\circledR}$ & 40 & 51.3 & & 14 & 23.7 \\
EUROIMMUN $^{\circledR}$ & 6 & 7.7 & & 0 & - \\
Focus $^{\circledR}$ & 32 & 41.0 & & 2 & 3.4 \\
\hline
\end{tabular}

ringer did not report travels to endemic regions. It remains unclear whether the WNV-specific antibodies are due to cross-reactive neutralising antibodies induced by other flaviviruses, as both persons with low NT titers also presented a low titre of YFV-neutralising antibodies (1:20 and $1: 10$, respectively).

When handling an infected bird, its faeces, saliva, and blood are the most likely sources of WNV or other zoonotic infections. Since several bird species are carriers of infectious agents and have been implicated in transmitting infections to bird ringers (Kokkarinen et al. 1994), it is conceivable that, especially in WNV-endemic regions like Africa or the Americas, individuals who are regularly exposed to wild birds might be at a higher risk of contracting a WNV infection by direct contact to infected wild birds or via mosquitoes. But, so far, no information is available regarding the risk of infection for bird ringers in endemic regions. In 2005, a case of WNV infection was observed in a bird watcher in Hungary (E. Ferenczi, personal communication). The present study gives the first data of the infection risk during bird ringing activities in Germany and Austria. In contrast to the epidemic situation in the USA, WNV outbreaks in Europe are temporally restricted. It is assumed that this depends on abiotic factors like the temperature. The low mean temperature in Germany and Austria decreases the risk of a year-round transmission of WNV by mosquitoes (Malkinson and Banet 2002). It was shown that the growth of WNV in mosquitoes is dependent on the mean ambient temperature (Reisen et al. 2006).

So far, no disease due to autochthonous WNV infection has been reported in Germany, either in humans or in birds. However, WNV infections in humans have been diagnosed in travelers returning from the USA (Jensen and Pauli 2004). Although WNV-seropositive birds can be found in Germany, a possible explanation of the low risk of acquiring a WNV infection during bird ringing in Germany and Austria might be that WNV-viremic birds rarely reach Germany, because of their reduced fitness, and stay in stopover points in south-eastern Europe like Romania, where WNV outbreaks were observed (Linke et al. 2007; Savage et al. 1999). There are no field data regarding the viremic profile in migrating birds. Only findings of experimentally infected birds are available. Viremic periods in birds of North America vary depending on the species. Whereas some birds did not develop a detectable viremia, others sustained it for 7 days (Komar et al. 2003). A further consideration concerns the aspect of natural resistance in migratory birds. It is assumed that birds have used the migration routes between Africa and Europe for a long period of time, and some of the species might have developed a natural resistance to WNV (Pauli 2004; Linke et al. 2007). 
As a result of our data we conclude that bird ringers as well as the German and Austrian population in general are at low risk of acquiring a WNV infection. The question whether migrating birds play an important role in disseminating viral diseases like avian influenza is still under discussion. New findings show that migratory waterfowl do not perpetuate the highly pathogenic H5N1 virus (Krauss et al. 2007). Although we found no evidence that bird ringing in Germany and Austria carries an increased risk of a WNV infection, we recommend adequate personal protection equipment during ringing activities.

\section{Zusammenfassung}

Bewertung des Infektionsrisikos mit dem West-Nil-Virus bei deutschen und österreichischen Vogelberingern

Das West-Nil-Virus (WNV) gehört zu den Arthropodenübertragenen Flaviviren. Vögel stellen dabei das natürliche Reservoir der Viren dar. Es gibt Stechmückenarten, die das Virus von Vögeln auf Menschen übertragen können. Der Erreger wird wahrscheinlich durch Zugvögel aus endemischen Regionen Afrikas nach Europa importiert. In der vorliegenden Studie wurde zum ersten Mal untersucht, inwieweit ein Risiko besteht, dass Vogelberinger sich durch den engen Kontakt zu Zugvögeln in Deutschland mit WNV infizieren. Seren von 137 deutschen und österreichischen Vogelberingern wurden serologisch mit Antikörpersuchtesten (ELISA- und Immunfluoreszenztest) untersucht. Ein Vergleich der verschiedenen serologischen Testsysteme zeigte, dass der WNV-ELISA und der Immunfluoreszenztest Kreuzreaktionen zu anderen Flaviviren aufweisen. In drei Seren wurden neutralisierende Antikörper gegen WNV nachgewiesen. Die Antikörperantwort zweier Personen konnte mit deren Reiseverhalten in WNVEndemiegebiete korreliert werden. Bei der dritten Person kann eine Kreuzreaktion mit anderen eng verwandten Flaviviren wie dem Frühsommer-Meningo-EnzephalitisVirus nicht ausgeschlossen werden. Daher wird der VirusNeutralisationstest als Goldstandard in der serologischen Flavivirusdiagnostik angesehen. Die Ergebnisse der Studie weisen darauf hin, dass derzeit ein Infektionsrisiko mit WNV bei Vogelberingern in Deutschland oder Österreich nicht erkennbar ist.

Acknowledgments We acknowledge the excellent technical assistance of Inga Nehlmeier and Anette Teichmann. We would also like to thank Miriam Wiese-Posselt, Mr. and Mrs. Wiese, Gabi Harder, Sönke Martens and Andreas Jansen for their help in blood sampling and Walter Foken, Franz Bairlein, Veit Henning, Peter Berthold, and Ulrich Köppen for their continuous support regarding the recruitment of participants. We also thank Hanna Bin, Sheba Medical Center,
Israel for providing us with WNV isolate Israel and Ursula Erikli for copy-editing. This study was financially supported by the German Ministry of Health, grant BMGS 115-1720-1/31. This study was approved by the ethical committee in charge and participants gave their written informed consent prior to enrollment.

\section{References}

Chiles RE, Reisen WK (1998) A new enzyme immunoassay to detect antibodies to arboviruses in the blood of wild birds. J Vector Ecol 23(2):123-135

Gubler DJ (2001) Human arbovirus infections worldwide. Ann NY Acad Sci 951:13-24

Hogrefe WR, Moore R, Lape-Nixon M, Wagner M, Prince HE (2004) Performance of immunoglobulin $\mathrm{G}$ ( $\mathrm{IgG})$ and $\mathrm{IgM}$ enzymelinked immunosorbent assays using a West Nile virus recombinant antigen (preM/E) for detection of West Nile virus- and other flavivirus-specific antibodies. J Clin Microbiol 42(10):46414648. doi:10.1128/JCM.42.10.4641-4648.2004

Hubalek Z (2000) European experience with the West Nile virus ecology and epidemiology: could it be relevant for the New World? Viral Immunol 13:415-426

Jensen E, Pauli G (2004) Germany: probable 3rd imported case of West Nile virus infection since 2003. ProMed (http://www.promedmail.org), 8 December 2004 accessed at number 20041208.3257

Kanesa-Thasan N, Putnak JR, Mangiafico JA, Saluzzo JE, Ludwig GV (2002) Short report: Absence of protective neutralizing antibodies to West Nile virus in subjects following vaccination with Japanese encephalitis or dengue vaccines. Am J Trop Med Hyg 66:115-116

Kokkarinen J, Tukiainen H, Seppa A, Terho EO (1994) Hypersensitivity pneumonitis due to native birds in a bird ringer. Chest 106:1269-1271

Komar N, Langevin S, Hinten S, Nemeth N, Edwards E, Hettler D, Davis B, Bowen R, Bunning M (2003) Experimental infections of North American birds with the New York 1999 strain of West Nile virus. Emerg Infect Dis 9:311-322

Krauss S, Obert CA, Franks J, Walker D, Jones K, Seiler P, Niles L, Pryor SP, Obenauer JC, Naeve CW, Widjaja L, Webby RJ, Webster RG (2007) Influenza in migratory birds and evidence of limited intercontinental virus exchange. PLoS Pathog 3(11):e167

Linke S, Niedrig M, Kaiser A, Ellerbrok H, Müller K, Müller T, Conraths FJ, Mühle RU, Schmidt D, Köppen U, Bairlein F, Berthold P, Pauli G (2007) Serologic evidence of West Nile virus infections in wild birds captured in Germany. Am J Trop Med Hyg 77:358-364

Malkinson M, Banet C (2002) The role of birds in the ecology of West Nile virus in Europe and Africa. Curr Top Microbiol Immunol 267:309-322

Malkinson M, Banet C, Weisman Y, Pokamunski S, King R, Drouet MT, Deubel V (2002) Introduction of West Nile virus in the Middle East by migrating white storks. Emerg Infect Dis 8:392-397

Marano N, Pappaioanou M (2004) Historical, new, and reemerging links between human and animal health. Emerg Infect Dis 10:2065-2066

MMWR (2002) Laboratory-acquired West Nile virus infectionsUnited States. Morb Mortal Wkly Rep 51:1133-1135

MMWR (2003) West Nile virus infection among turkey breeder farm workers-Wisconsin. Morb Mortal Wkly Rep 52:1017-1019

Pauli G (2004) West Nile virus. Prevalence and significance as a zoonotic pathogen. Bundesgesundheitsblatt Gesundheitsforschung Gesundheitsschutz 47(7):653-660 
Rappole JH, Derrickson SR, Hubalek Z (2000) Migratory birds and spread of West Nile virus in the Western hemisphere. Emerg Infect Dis 6(4):319-327

Reisen W, Brault AC (2007) West Nile virus in North America: perspectives on epidemiology and intervention. Pest Manag Sci 63(7):641-646. Epub March 20

Reisen WK, Fang Y, Martinez VM (2006) Effects of temperature on the transmission of West Nile virus by Culex tarsalis (Diptera: Culicidae). J Med Entomol 43:309-317
Savage HM, Ceianu C, Nicolescu G, Karabatsos N, Lanciotti R, Vladimirescu A, Laiv L, Ungureanu A, Romanca C, Tsai TF (1999) Entomologic and avian investigations of an epidemic of West Nile fever in Romania in 1996, with serologic and molecular characterization of a virus isolate from mosquitoes. Am J Trop Med Hyg 61:600-611. Erratum in: Am J Trop Med Hyg 2000 62:162

Sutherst RW (2004) Global change and human vulnerability to vector-borne diseases. Clin Microbiol Rev 17:136-173 